\title{
Current Development on Social Media Platform for Green Library Technology Initiative
}

\author{
Mazwani Ayu Mazlan (corresponding author) \\ Faculty of Information Management \\ Universiti Teknologi MARA, UiTM Selangor, Malaysia \\ Tengku Adil Tengku Izhar \\ Faculty of Information Management \\ Universiti Teknologi MARA, UiTM Selangor, Malaysia \\ Mohammad Fazli Baharuddin \\ Faculty of Information Management \\ Universiti Teknologi MARA, UiTM Selangor, Malaysia \\ Mohd Shamsul Mohd Shoid \\ Faculty of Information Management \\ Universiti Teknologi MARA, UiTM Selangor, Malaysia
}

Received: July 16, 2018 Accepted: August 24, 2018 Published: September 13, 2018

doi:10.5296/ijld.v8i3.13650 URL: https://doi.org/10.5296/ijld.v8i3.13650

\begin{abstract}
There has been wide academic and research interest in the application of social media modalities, as instructional tools, in contemporary educational settings. Although research on this topic has grown exponentially in recent years, very little is known about the breadth of research regarding the engagement of social media to empower green library initiative for sustainability community. This paper aims to obtain current development on social media engagement that influence library to implement green initiative for sustainability community. In order to achieve this aim, the study reviews the literature hence for analysis and synthesis
\end{abstract}


of literature on social media, library and green technology. In this paper, all related and relevant primary, secondary and tertiary sources are referred. The significant of this paper will assist future development of research framework based social media to empower green library initiative.

Keywords: Green technology, green library, library science, literature review, social media

\section{Introduction}

Social media presents a decent number of chances for libraries, yet in addition numerous difficulties (Matthews, 2011a, 2011b; Newman, 2012; Thurston, 2012). For instance, social media has helped Lambeth chamber in London to select several 'green champions' to help networks to make a move to enhance their condition. The ward presently has 60 natural gatherings and 150 network nourishment developing ventures lessening contamination and activity while urging individuals to cooperate, learn new aptitudes, exercise and deliver sound sustenance. This is a piece of the territory's endeavors to enhance the soundness of occupants and innovation has a critical part to play. From creating efficient power vitality and enhancing reusing to empowering freedom and lessening separation innovation can possibly enable our networks to end up more earth, financially and socially maintainable. Try to guarantee innovation, for example, web based life is use to associate individuals in a typical undertaking and that the individuals who most need it, the poorest and the most established, are not prohibited through absence of assets or support.

At present, there is restricted separation in how social media channels are utilized to advance green innovation. Comparable goals and strategies apply over every social medium devices, yet it is visualized that this will change quickly with systems ending up progressively channel-particular. Social media can give numerous valuable advantages to the individual or association developing and advancing its practical green character and activities. In a positive, strong soul of supportability and green activities, the accompanying thoughts are offered to guarantee that the utilization of web based life is progressively fruitful and helpful, in that, it adds to key development and administration including arranging, usage, and control (Williams et al., 2014). Online life can be utilized for green organizations by giving the incentive to the customer in the examination of items and administrations (Matthews, 2011; Matthews, 2011).

Social media has the manageable to facilitate much closer relationship between libraries and their customers (Matthews, 2011a, 2011b; Newman, 2012; Thurston, 2012). Current utilization of social media by way of the library neighborhood generally remains advert hoc and truly experimental but they in all likelihood play an vital role in library provider provision and outreach the future (Ny et al., 2006; Orsato, 2006; Sikdar et al., 2004; Trotta, 2010). Social media affords a properly range of possibilities for libraries, however additionally many challenges. The primary possibilities related inexperienced initiative of libraries the usage of social media are seen to be related to its low value (Charnigo \& Barnett-Ellis, 2007; Chu \& Nalani-Meulemans, 2008; Rosa et al., 2007). At the equal time, its ability to take the library provider to users in their favored spaces, the probability to construct a experience of inexperienced community between the library and its users, to help 
co-development of collections and help maintain librarians updated on enterprise news and initiatives (Ayu \& Abrizah, 2011; Cornell, 2010). Challenges are the massive time that is required to preserve an active social media presence, the pressure to reply right away to provider queries, the variability of skills throughout library staff for the usage of social media effectively, putting the proper tone between expert and personal, coordinating activities across the institution to keep away from duplication, retaining visibility for the library company and copyright issues concerning to web hosting library assets on social media sites.

This paper aims to survey current advancement via web-based networking media stage to advance green library innovation. To accomplish this point, we review past study via web-based social media to advance green activity in the library. The investigation audits the writing subsequently for examination and combination of writing via web-based networking media, library and green innovation. In this paper, all related and important essential, optional and tertiary sources are alluded. In this time of huge information science, it is basic for associations and organizations to have the capacity to grasp this new office and to precisely coordinate the learning based from various sources into the hierarchical data storehouse that permit green initiative.

The remainder of this paper is organized as follows. Section 2 is literature review. Section 3 is discussion. Section 4 is future works. The final section contains the concluding remarks

\section{Literature Review}

\subsection{Social Media}

The utilization of social media advances, for example, web journals, wikis, long range informal communication destinations, social networking, and smaller scale blogging is multiplying at an inconceivable pace to advance green activity (Treem \& Leonardi, 2012). The adjust may move as the significance of green issues, and the outcomes of disregarding them, increment. Nonetheless, spreading the genuine picture of genuine green will probably need to rise above customary media channels (Williams et al., 2014). As per William et al. (2014), most green interpersonal organizations practice, yet that might be a relic of their relative adolescence. A couple of green informal organization destinations have developed to the point of being really thorough.

Considering that the utilization of social media for green activities can have numerous constructive advantages (Matthews, 2011; Matthews, 2011; Newman, 2012; Thurston, 2012) For example, to expand and manufacture your green image by let accomplices, prospects, and clients become more acquainted with the individual and expert identity behind your green organization. As of late, the fast improvement of Web, Internet of Things, and Cloud Computing have prompted the unstable development of information in relatively every industry and business territory. Enormous information has quickly formed into an intriguing issue that pulls in broad consideration from the scholarly world, industry, and governments around the globe. There are numerous difficulties in bridling the capability of enormous information today, going from the outline of preparing frameworks at the lower layer to investigation implies at the higher layer, and a progression of open issues in logical research. 


\section{$\underline{\Lambda \text { Macrothink }}$}

Enormous information preparing frameworks appropriate for taking care of a decent variety of information writes and applications are the way to supporting logical re-inquiry of huge information (Jin et al., 2015). Long range informal communication devices (e.g., Twitter, LinkedIn, Facebook, MySpace) have been multiplying on the web.

Social media are changing the way data goes inside and between systems of people (Gangadharbatla et al., 2014). In spite of the fact that the exploration on informal organizations goes back to mid 1920s, by the by, social media investigation is an early field that has risen after the approach of Web 2.0 in the mid 2000s. The key normal for the advanced web-based social networking examination is its information driven nature. Online networking investigation allude to the examination of organized and unstructured information from internet based life channels. Social Media is a wide term including an assortment of online stages that enable clients to make and trade content. Client created content (e.g., estimations, pictures, recordings, and bookmarks) and the connections and communications between the system substances (e.g., individuals, associations, and items) are the two wellsprings of data in web based life (Gandomi \&Haider, 2015).

Online networking have significantly changed our lives and how we communicate with each other and our general surroundings (Qualman, 2009; Safko \& Brake, 2009). Late research shows that an ever increasing number of individuals are utilizing web-based social networking applications, for example, Facebook and Twitters for different reasons, for example, making new companions, associating with old companions, accepting data, and engaging themselves (Kaplan \& Haelein, 2010; Keckley, 2010; Stop et al., 2009; Raacke \& Bonds-Raacke, 2008). Social media examination will separate an incentive from tremendous measure of online life information to identify and find new learning to see how industry is changing, and utilize the discoveries and enhanced comprehension to accomplish upper hand against their rivals (Governatori \& Iannella, 2011; He et al., 2013). Social media focused examination enables a business to increase conceivable business advantage by breaking down the freely accessible web based life information of a business and its rivals (He et al., 2013). As social media have turned into a theme of enthusiasm for some businesses, it is vital to see how online life information can be reaped for basic leadership (He et al., 2013).

With the advancement of savvy gadgets and distributed computing, an ever increasing number of open information can be gathered from different sources and can be investigated in an exceptional way. The tremendous social and scholarly effect of such improvements caused an overall buzz for huge information (Huang et al., 2015). Information stream is an arranged succession, which is continuous, fast, endless and time differing. It's additionally of awesome significance in web administration, web security and web test. Be that as it may, with the quick improvement of web innovation, the quantity of web applications and clients continues rising, and the web information is developing exponentially (Zhi et al., 2011). There are stricter prerequisites about the effectiveness, expandability and dependability of the information stream in social media. 


\subsection{Social Media Roles in Library}

Most libraries figure they don't have any part in long range informal communication (Rosa et al., 2007). Notwithstanding, contemplate by Chu \& Nalani-Meulemans (2008) and Charnigo \& Barnett-Ellis (2007) showed social media assist administrators with staying associated with the clients. As of late, Kai-Wah and Du (2012) showed how the utilization of social media by library has now progressed toward becoming standard. For instance, in Asia, North America and Europe, $71 \%$ were observed to utilize social media instruments with a further $13 \%$ saying they wanted to utilize them. Facebook and Twitter were the most usually utilized devices. Ayu and Abrizah (2011) demonstrated the utilizes content examination to look at current employments of the library Facebook page. A checkpoint was created to examine the libraries' utilization and use of Facebook page. The writers investigates the utilization and use of Facebook among Malaysian scholarly libraries so as to give scholastic libraries thoughts for best practices in utilizing long range informal communication destinations to better profile themselves and discuss viably with their clients.

Tyler (2012) examined the expanding enthusiasm for social media, the advertising venture officers were quick to investigate how they could be utilized by administrators and library administrations. In any case, they didn't wish to set out on battles which utilize social media if library staff and clients can't get to them. In view of this examination, confirm recommended that numerous administrators were kept from getting to online networking devices in a work setting, and that entrance shifted over the diverse library divisions.

Zhoorian-Fooladi (2014) showed that the custodians utilize social media to advance library administrations, oversee authoritative information and accepting moment input from clients. Work process snags, innovation deterrents, hierarchical impediments and individual obstructions deflect custodians from taking an interest in online networking.

Numerous libraries are as of now trying different things with various online networking administrations like Twitter or Facebook to collaborate and interface with their supporters, yet there are as yet various inquiries that surface as this is a still genuinely new area (Burkhardt, 2010).

Table 1. Analysis of review on social media in library.

\begin{tabular}{|c|c|c|c|c|}
\hline Authors & Services & Networking & Marketing & Green Library \\
\hline Zhoorian-Fooladi (2014) & 1 & & 1 & $x$ \\
\hline Tyler (2012) & & & l & $x$ \\
\hline Bukhardt (2010) & & / & & $x$ \\
\hline Charnigo \& Barnett-Ellis ( 2007) & & & & $x$ \\
\hline Chu \& Nalani-Meulemans ( 2008) & & / & & $x$ \\
\hline Kai-Wah \& Du (2012) & & 1 & & $x$ \\
\hline
\end{tabular}


Small steps in going green can have a large have an impact on for the library's photograph (Zhoorian-Fooladi, 2014). The core of a green library is to be considered to be making dependable environmental statistics without problems accessible. The availability of a mechanism that allows seamless consolidation of understanding from external sources will enrich the functionality of the employer to make accurate decision-making for inexperienced technology (Tyler, 2012; Zhoorian-Fooladi, 2014). These heterogeneous exterior sources are developing very significantly in the closing few years, mainly due to the availability of wireless and cell technologies, crowd-sourcing facilities, Internet of Things and sensor networks, as properly as social media and internet data. All these technologies generate big amount of information and together they can be extracted to generate values to the corporation and to set up situational attention of the neighborhood or market trends.

There has been large academic and lookup pastime in the utility of social media modalities, as academic tools, in modern-day educational settings. Although research on this subject has grown exponentially in recent years, very little is recognized about the breadth of lookup involving the engagement of social media to empower inexperienced library initiative for sustainability community, as proven in Table 1 . There is restricted framework develop that include social media to promote the essential of inexperienced science in library. Currently there is confined framework that differentiation in how social media channels are used to promote green technology. Similar goals and procedures follow throughout all social media tools, but it is envisaged that this will alternate unexpectedly with techniques turning into increasingly more channel-specific. The aim of this paper is to endorse a framework based totally social media to empower green technology initiative for library sustainability. In order to acquire this aim, we evaluation the literature for this reason for evaluation and synthesis of preceding present model on social media, library and inexperienced technological know-how for the development of the future framework.

\subsection{Green Library Sustainability Initiative}

Libraries are responsible for scattering data on natural maintainability as well as for filling in as cases to take after. Little strides in becoming environmentally viable can bigly affect the library's picture (Hauke et al., 2013). As indicated by Hauke and Werner (2013), environmental supportability which can regularly be an underestimated perspective for the advertising technique of the library, has more effect on customers and on partners than one may anticipate. Energetic library clients are approaching libraries not simply to give well known administrations but rather to convey a reasonable green personality. Albeit "Green advertising" today prompts $1,100,000$ Google indicates, a "green" library picture as a showcasing device, or "green" library promoting methodologies appear expressis verbis never to be portrayed nor talked about in the LIS writing.

An open library might be a piece of a system of the regions: the library can feature the district's green profile and this could be a decent advertising procedure (Hauke et al., 2013). The production of green libraries is moving toward a tipping point, creating a Green Library Development, which is involved custodians, libraries, urban areas, towns, school and college grounds focused on greening libraries and decreasing their ecological effect (Antonelli, 2008). 
The measure of data accessible on green libraries and green library rehearses is constrained yet keeps on developing. Libraries are confided in network foundations, which makes them perfect areas for green innovation shows and deliberately positions them to wind up network models for supportability (Barnes, 2012).

There are numerous alternatives and degrees to which an organization can separate itself as a decent green, manageable national; and, there are numerous productive commitments that could be made by web-based social networking to get the green messages out with the coveted outcome (Williams et al., 2014). The system of going "green" speaks to a to some degree moving target. Supportability shifts broadly relying on the item lifecycle arrange being dissected, and in addition backhanded impacts from the store network (Ny et al., 2006; Sikdar et al., 2004). For instance, green washing has turned out to be basic as of late, principally because of an absence of control, oversight, and checking of green promoting claims (Dahl, 2010; Ramus \& Montiel, 2005). Numerous libraries are hesitant to embrace green development procedures except if there are clear money saving advantages from doing as such in light of the fact that such here and now ventures for long haul returns are viewed as dangerous in professional workplaces where execution is judged and in view of here and now quarterly returns. Be that as it may, for the audacious, an all encompassing coordination of green into whole item lifecycle merits handling on account of the development potential it offers. Outlining a plan of action around the necessities of nature, rather than retrofitting existing models to be more eco-accommodating, is fundamentally imaginative, and holds the guarantee of both industry authority, buyer altruism, and premium valuing (Chen \& Lin, 2011; Ginsberg \& Sprout, 2004). These enterprises utilize green advancement procedures as an upper hand and are the destined to get government bolster for their endeavors (Orsato, 2006). The open door is coordinated by the hazard. In any case, such models are deliberately imbalanced, trading off efficiency for nature, and may not be practical in the more extended term (Trotta, 2010).

Albeit numerous libraries as of now have a day by day green standard, for example, reusing, twofold sided duplicates, turning the lights off when not required and so on, most don't wander past these nuts and bolts. There are a considerable measure of cases with reference to how libraries can deal with such issues in an easy to use way, and how they approach advertising their individual endeavors (Hauke et al., 2013).

\section{Discussion}

\subsection{Social Media Platform to Promote Green Library}

Social media networking can possibly encourage substantially nearer connection amongst libraries and their clients. Current utilization of online life by the library network for the most part remains specially appointed and to some degree exploratory however they likely assume a vital part in library benefit arrangement and effort what's to come. Online networking presents a decent number of chances for libraries, yet additionally numerous difficulties.

Ongoing flooding research and other extraordinary climate occasions are the most clear signs that except if we live more economically we will confront progressively scriptural outcomes. 
Strict tempests have touched base inside a horrible financial atmosphere, prompting cuts that undermine the social care, wellbeing and different administrations that a maturing and undesirable populace depends on in expanding numbers. Industrialization and hey tech money related markets got us into this wreckage. Presently innovation, if used to engage individuals and networks, holds the way to making an economical future.

The main opportunities associated green utilizing social media are believed to be identified with its minimal effort. In the meantime, its capacity to take the library administration to clients in their favored spaces, the chance to construct a feeling of green network between the library and its clients, to help co-improvement of accumulations and help keep bookkeepers refreshed on industry news and activities. Difficulties are the impressive time that is required to keep up a functioning web based life nearness, the strain to react quickly to benefit questions, the inconstancy of aptitudes crosswise over library staff for utilizing internet based life successfully, striking the correct tone amongst expert and individual, planning exercises over the organization to stay away from duplication, keeping up perceivability for the library brand and copyright issues identifying with facilitating library assets via web-based networking media locales.

There are numerous choices and opportunities to which an organization can separate itself as a decent green, economical national; and, there are numerous helpful commitments that could be made by social media to get the green messages out with the coveted outcome (Williams et al., 2014).The methodology of going "green" speaks to a fairly moving target. Supportability changes broadly relying on the item lifecycle organize being broke down, and additionally circuitous impacts from the production network (Ny et al., 2006; Sikdar et al., 2004).

Numerous libraries are hesitant to receive green development techniques except if there are clear money saving advantages from doing as such on the grounds that such here and now speculations for long haul returns are viewed as hazardous in professional workplaces where execution is judged and in light of here and now quarterly returns. Notwithstanding, for the daring, an all encompassing incorporation of green into whole item lifecycle merits handling in light of the development potential it offers (Ginsberg \& Sprout, 2004). As of now there is restricted separation in how social media channels are utilized to advance green innovation. Comparative destinations and strategies apply over every single social medium instruments, however it is visualized that this will change quickly with systems ending up progressively channel-particular.

Social media can give numerous valuable advantages to the individual or association developing and advancing its economical green character and activities. In a positive, steady soul of supportability and green activities, the accompanying thoughts are offered to guarantee that the utilization of social media is progressively effective and helpful, in that, it adds to vital development and administration including arranging, usage, and control (Matthews, 2011). Online networking can be utilized for green organizations by giving the incentive to the shopper in the correlation of items and administrations (Matthews, 2011; Matthews, 2011). 


\subsection{Green Initiative Opportunity}

The main opportunities related green activity of libraries utilizing social media are believed to be identified with its minimal effort. In the meantime, its capacity to take the library administration to clients in their favored spaces, the chance to assemble a feeling of green network between the library and its clients, to help co-improvement of accumulations and help keep administrators refreshed on industry news and activities (Cornell, 2010). Difficulties are the impressive time that is required to keep up a functioning web-based social networking nearness, the strain to react immediately to benefit questions, the changeability of abilities crosswise over library staff for utilizing web-based social networking successfully, striking the correct tone amongst expert and individual, planning exercises over the foundation to dodge duplication, keeping up perceivability for the library brand and copyright issues identifying with facilitating library assets via web-based networking media locales. Little strides in practicing environmental awareness can have a major effect for the library's picture. The center of a green library is to be believed to make dependable ecological data effortlessly open. The accessibility of a component that permits consistent solidification of information from outer sources will enhance the capacity of the association to settle on precise basic leadership for green innovation. These heterogeneous outer sources are becoming altogether over the most recent couple of years, particularly because of the accessibility of remote and versatile advances, swarm sourcing offices, Internet of Things and sensor systems, and also web based life and web information. Every one of these advances produce colossal measure of information and together they can be removed to create esteems to the association and to build up situational attention to the network or market patterns.

\section{Significant and Future Works}

The study reviews the literature consequently for analysis and synthesis of literature on social media, library and inexperienced technology. In this paper, all associated and applicable primary, secondary and tertiary sources are referred. In this technology of large facts science, it is essential for organizations and organizations to be in a position to embrace this new facility and to precisely combine the knowledge-bases from multiple sources into the organizational data repository that allow inexperienced inititiative. The availability of a mechanism that allows seamless consolidation of expertise from exterior sources will enrich the capability of the employer to make correct decision-making for green technology. These heterogeneous external sources are growing very notably in the remaining few years, specially due to the availability of wi-fi and mobile technologies, crowd-sourcing facilities, Internet of Things and sensor networks, as properly as social media and web data. All these applied sciences generate large quantity of facts and together they can be extracted to generate values to the employer and to establish situational focus of the community or market trends.

The study will enhance library profitability to advance library administrations and practices. Such administrations and practice will bring qualities to advance dependability between libraries, clients and industry contract. The examination will enhance the capacity of all around educated connection amongst libraries and clients to practice their law based rights and to assume a functioning part in the public arena. In the meantime, the exploration will 
restrain particular from the handy part of sharing assets in that libraries give a physical place to instructors and students to meet and work together with assemble a feeling of network that can improve educating and learning process with different establishments. Later on, we will propose a structure based social media to assess the execution of green innovation for library manageability. The structure can be connected to gauge clients point of view that engage the use of web based life as a principle stage to assess the adequacy of internet based life in advancing the activity of green innovation in library

\section{Conclusion}

Social media is a stage to encourage the connection amongst libraries and their clients. Social media is sensibly all around inserted in library and its moving towards a focal part in how libraries are speaking with their end clients. In the meantime, its capacity to take the library administration to clients in their favored spaces, the chance to construct a feeling of network between the library and its clients, to help co-improvement of accumulations and help keep bookkeepers refreshed on industry news and activities. Social media is critical to assist library with transforming a piece of human learning that can improve human information by utilizing specific learning innovation from web based life. This innovation will enhance execution in managing the library condition, work execution and proficient administration conveyance for more aggressive and gainful economy that can help make manageable networks. In this manner, having a capacity to break down data from social media in an auspicious manner can guarantee libraries have a focused edge to enhance efficiency in connection to create instructing and learning condition.

\section{Acknowledgements}

The authors would like to extend our deepest gratitude to the Universiti Teknologi MARA (UiTM) for financing this project under the "Dana UiTM Cawangan Selangor" (DUCS ). Reference 600-UiTMSEL (PI. 5/4) (007/2018). Our thanks are also dedicated to Department of Research and Innovation Centre, Universiti Teknologi MARA (UiTM) Puncak Alam, Selangor Campus for facilitating us towards the completion of the project.

\section{References}

Antonelli, M. (2008). The Green Library Movement: An Overview and Beyond. Elecronic Green Journal, 1(27), 1-11.

Ayu, A. R., \& Abrizah, A. (2011). Do you Facebook? Usage and applications of Facebook page among academic libraries in Malaysia. The International Information \& Library Review, 43(4), 239-249. https://doi.org/10.1080/10572317.2011.10762906

Burkhardt, A. (2010). Social Media: A guide for college and university libraries. College and Research Libraries News, 70(1), 10-24. https://doi.org/10.5860/crln.71.1.8302

Charnigo, L., \& Barnett-Ellis, P. (2007). Checking out Facebook.com: The impact of a digital trend on academic libraries. Information Technology and Libraries, 26(1), 23-34. https://doi.org/10.6017/ital.v26i1.3286 
Chen, C.-S., \& Lin, L.-Y. (2011). A New Framework: Make Green Marketing Strategy go with Competitive Strategy. Retrieved 17 March, 2016, from http://www.jgbm.org/page/20\%20Chun-Shuo\%20Chen.pdf

Chu, M., \& Nalani-Meulemans, Y. (2008). The problems and potential of MySpace and Facebook usage in academic libraries. Internet Reference Services Quarterly, 13(1), 69-85. https://doi.org/10.1300/J136v13n01_04

Cornell, V. (2010). Greening the library: Collection development decisions. The Journal of New Members Round Table, 1(1), 1-15.

Dahl, R. (2010). Green washing: Do you know what you're buying? . Environmental Health Perspectives, 118(6), A246-A252. https://doi.org/10.1289/ehp.118-a246

Gandomi, A., \& Haider, M. (2015). Beyond the hype: Big data concepts, methods and anlytics. International Journal of Information Management, 35, 137-144. https://doi.org/10.1016/j.ijinfomgt.2014.10.007

Gangadharbatla, H., Bright, L. F., \& Logan, K. (2014). Social media and news gathering: tapping into the millennial mindset. The Journal of Social Media in Society, 3(1), 45-63.

Ginsberg, J. M., \& Bloom, P. (2004). Choosing the Right Green Marketing Strategy. MIT Sloan Management Review, 4(1), 77-84.

Governatori, G., \& Iannella, R. (2011). A modeling and reasoning framework for social networks policies. Enterprise Information Systems, 5(1), 145-167. https://doi.org/10.1080/17517575.2010.513014

Hauke, P., Latimer, K., \& Werner, K. U. (2013). The Green Library: The challange of environmental sustainability. IFLA Publications 161. Retrieved from http://edoc.hu-berlin.de/miscellanies/greenlibrary-42062/379/PDF/379.pdf

He, W., Zha, S., \& Li, L. (2013). Social media competitive analysis and text mining: A case study in pizza industry. International Journal of Information Management 33, 464-472. https://doi.org/10.1016/j.ijinfomgt.2013.01.001

Huang, T., Lan, L., Fang, X., An, P., Min, J., \& Wang, F. (2015). Promises and challenges of big data computing in health sciences. Big Data Research, 2(1), 2-11. https://doi.org/10.1016/j.bdr.2015.02.002

Jin, X., Wah, B. W., Cheng, X., \& Wang, Y. (2015). Significance and challenges of big data research. Big Data Research, 2, 59-64. https://doi.org/10.1016/j.bdr.2015.01.006

Kai-Wah C, S., \& Du, H. S. (2012). Social Networking Tools for Academic Libraries. Journal of Librarianship and Information Science, 45(1), 64-75.

Kaplan, A. M., \& Haelein, M. (2010). Users of the worl, united! The challenges and opportunities of Social Media. Business Horizons, 53(1), 59-68. https://doi.org/10.1016/j.bushor.2009.09.003 
Keckley, P. H. (2010). Social networks in health care: Communication, collaboration and insights. Retrieved from http://www.deloitte.com/ assets/Dcom-UnitedStates/Local\%20Assets/Documents/US CHS 2010Social Networks 070710.pdf

Barnes, L. L. (2012). Green Buildings as Sustainability Education Tools. Retrieved 17 March, 2016, from https://www.ideals.illinois.edu/bitstream/handle/2142/34138/Green\%20Buildings\%20as\%20 Sustainability\%20Education\%20Tools\%20deposit\%20version.pdf?sequence $=2$

Matthews, R. (2011a). 50 best blogs for green business students. The Green Market Oracle. Retrieved $15 \quad$ March, from http://www.thegreenmarketoracle.com/2011/03/50-best-blogs-for-green- business.html

Matthews, R. (2011b). Social media marketing and environmental sustainability. The Green Market Oracle. $\quad 15$ Retrieved March, 2016, from http://www.thegreenmarketoracle.com/2011/02/social-media-marketing-and.html

Newman, W. (2012). Strategic intent for green marketing and disclosure using social media. Sustainable Business Forum. Retrieved 15 March, 2016, from http://sustainablebusinessforum.com/williamnewman/57188/strategic-intent-green-marketing -and- disclosure-using-social-media

Ny, H., MacDonald, J. P., Broman, G., Yamamoto, R., \& Robert, K.-H. (2006). Sustainability constraints as system boundaries: An approach to making life-cycle management strategic. Journal of Industrial Ecology, 10(1), 61-77. https://doi.org/10.1162/108819806775545349

Ny, H., MacDonald, J.P., Broman, G., Yamamoto, R., \& Robert, K. H. (2006). Sustainability Constraints as System Boundaries: An Approach to Making Life-Cycle Management $\begin{array}{lllll}\text { Strategic. Journal of Industrial Ecology, } & 10(1),\end{array}$ https://doi.org/10.1162/108819806775545349

Orsato, R. J. (2006). Competitive environmental strategies: When does it pay to be green? California Management Review, 48(2), 127- 143. https://doi.org/10.2307/41166341

Park, N., Kee, K. F., \& Valenzuela, S. (2009). Being immersed in social networking environment: Facebook groups, uses and gratifications, and social outcomes CyberPsychology \& Behavior, 12(6), 729-733. https://doi.org/10.1089/cpb.2009.0003

Qualman, E. (2009). Socialnomics how social media transforms the way we live and do business. Hoboken: Wiley John \& Sons, Inc.

Raacke, J., \& Bonds-Raacke, J. (2008). MySpace and Facebook: Applying the uses and gratifications theory to exploring friend-networking sites. CyberPsychology \& Behavior, 11(2), 169-174. https://doi.org/10.1089/cpb.2007.0056

Ramus, C. A., \& Montiel, I. (2005). When are corporate environmental policies a form of greenwashing? Business Society, 44(4), 377-414. https://doi.org/10.1177/0007650305278120 


\section{Macrothink}

International Journal of Learning and Development

ISSN 2164-4063 2018, Vol. 8, No. 3

Rosa, C. D., Cantrell, J., \& Havens, A. (2007). Sharing, privacy and trust in our networked world: A report to the OCLC membership. Dublin.

Safko, L., \& Brake, D. K. (2009). The social media bible: Tactics, tools, and strategies for business success. Hoboken: Wiley John \& Sons, Inc.

Sikdar, S. K., Glavic, P., \& Jain, R. (2004). Technological Choices for Sustainability. New York: Springer. https://doi.org/10.1007/978-3-662-10270-1

Thurston, B. (2012). The social media road map. Fast Company, 168, 69-80

Treem, J. W., \& Leonardi, P. M. (2012). Social Media Use in Organizations: Exploring the Affordances of Visibility, Editability, Persistence, and Association. Communication Yearbook, 36, 143-189.

Trotta, M. G. (2010). Product lifecycle management: Sustainability and knowledge management as keys in a complex system of product development. Journal of Industrial $\begin{array}{lll}\text { Engineering } \quad \text { and } & \text { 309-322. }\end{array}$ https://doi.org/10.3926/jiem.2010.v3n2.p309-322

Tyler, A. (2012). Welsh Libraries and Social Media: A Survey. Ariadne.

Williams, K. C., Page, R. A., \& Petrosky, A. R. (2014). Green Sustainability and New Social Media. 9(1), 11-13.

Zhi, Q., Zhao-Wen, L., \& Yan, M. (2011). Research of Hadoop-based data flow management system. The Journal of China Universities of Post and Telecommunications, 18, 164-168. https://doi.org/10.1016/S1005-8885(10)60140-9

Zhoorian-Fooladi, N. (2014). Academic librarians and their social media presence: a story of motivations and deterrents. Information Development, 30(2), 159-171. https://doi.org/10.1177/0266666913481689

\section{Copyright Disclaimer}

Copyright for this article is retained by the author(s), with first publication rights granted to the journal.

This is an open-access article distributed under the terms and conditions of the Creative Commons Attribution license (http://creativecommons.org/licenses/by/4.0/). 